UDC 342.4(497.11)

Tanja Arsić, advokat u Novom Sadu

\title{
NEKI STAVOVI U POGLEDU BUDUĆEG NORMIRANJA POGLAVLJA O PRAVOSUĐU NA TREĆEM OKRUGLOM STOLU O IZMENAMA USTAVA REPUBLIKE SRBIJE*
}

Tema Trećeg okruglog stola o izmenama Ustava Republike Srbije održanog 30. 10. 2017. god. u Novom Sadu, bila je „Izvori prava i sudska praksa“. Okrugli sto je otvorio Čedomir Backović, pomoćnik ministra pravde zadužen za evropske integracije i međunarodne projekte. Uvodna izlaganja su imali Tanja Miščević, šef pregovaračkog tima za vođenje pregovora o pristupanju RS Evropskoj uniji, i Žarko Stepanović, v. d. direktora Kancelarije za saradnju sa civilnim društvom. Iako je tema u agendi data na način kako je napisano, Ministrastvo pravde je u propratnom materijalu postavilo pitanje o sudskoj praksi kao izvoru prava i zatražilo odgovore na isto od učesnika diskusije.

U svom uvodnom govoru Čedomir Backović se osvrnuo na ulogu „takozvane stručne javnosti“ u diskusijama i primedbama na teme okruglih stolova kao i o advokaturi i advokatima kao pružaocima usluga.

U svojstvu učesnika na okruglom stolu ukazala sam na sledeće:

- opravdano očekivanje da advokatura nije podvedena pod „takozvanu stručnu javnost";

- izrazito neslaganje sa svrstavanjem advokature i advokata u pružaoce usluga, jer advokatura ne učestvuje u tržišnoj utakmici već pruža pravnu pomoć. Istakla sam da je Venecijanska komisija prilikom ocene odredaba Ustava RS, u tački 40. jedinu pozitivnu ocenu dala upravo

${ }^{*}$ Rad primljen 31. 10. 2017. godine. 
članu 67. koji govori o tome da pravnu pomoć pružaju advokatura i jedinice lokalne samouprave. Ocena Venecijanske komisje glasi: „Ova odredba ide dalje od Evropske konvencije o ljudskim pravima, što je veoma pozitivno." Postavila sam i pitanje kakvo opravdanje bi izvršna vlast imala za izmenu takvog člana;

- s obzirom da nijedna tema okruglih stolova vezanih za pravosuđe ne obuhvata advokaturu, iznela sam stav da nijedna definicaja advokature ne postoji bez određenja advokature kao dela pravosudnog sistema.

O ulozi advokature sam istakla sledeće:

1. advokatura pruža stručnu pravnu pomoć i značajno doprinosi pravilnoj primeni zakona odnosno predstavlja svojevrsni kontrolni mehanizam u primeni zakona od strane sudova;

2. advokati su dužni da se pridržavaju Kodeksa profesionalne etike advokata što izostaje na strani odnih koji zastupaju stanovište da krug pružaoca pravne pomoći treba da se proširi;

3. advokati imaju zabranu obavljanja nespojivih poslova;

4. advokati imaju obavezu mirnog rešenja spora tamo gde je to moguće;

5. advokatima je zabranjeno davanje izjava štampi radi sticanja lične popularnosti;

6. advokate vezuje profesionalna tajna;

7. advokati odgovaraju celokupnom imovinom za svoj rad.

I ono što advokaturu izdvaja od svih potencijalnih novih pružaoca pravne pomoći:

8. advokati poseduju građansku hrabrost kada kreću u potragu za pravdom.

Ukazala sam na to da su prema čl. 67. Ustava RS, jedino advokati i jedinice lokalne samouprave ovlašćeni na pružanje pravne pomoći, a sledstveno tome i besplatne pravne pomoći. Advokatura je jedina stručno osposobljena, samostalna i nezavisna i jedina ima široko razgranatu mrežu na teritoriji cele Srbije. Besplatna pravna pomoć koju je izvršna vlast do sada predlagala bi bila pružana od strane pravnih klinika, nevladinih organizacija, studenata i ostalih. Ova lica nisu stručno osposobljena da pružaju pravnu pomoć, a povrh svega vezani su za veće gradova tako da bi korisnici besplatne pravne pomoći, koji su već u iznudici, morali da prevaljuju po nekoliko stotina kilometara da bi ovakvu vrstu pomoći dobili. Advokati su prisutni u gotovo svim mestima u Srbiji.

Osvrnula sam se na dosadašnje teme okruglih stolova i iznela da tema Pravosudna akademija, ne zaslužuje da bude tema okruglog stola. Ocena Venecijanske komisije da je potrebno eliminisanje uticaja politike na izbor nosilaca pravosudnih funkcija, odnosno da se izbor ne vrši u Skupštini, prebačen je na predlog izvršne vlasti u nadležnost Pravosudne akademije. Time je otvorena 
mogućnost da se utiče na to ko će biti upisan na Pravosudnu akademiju i time izvši prethodna selekcija. Pravosudna akademija zbog ovako zamišljene uloge ne može biti ustavna kategorija. Paradoksalno je da Srpska akademija nauka i umetnosti nije ustavna kategorija.

Što se tiče sudske prakse kao izvora prava iznela sam mišljenje da naš sistem, koji pripada kontinentalnom pravnom sistemu, nije prilagođen uvođenju precedentnog prava i da je to proces koji može da se odvija godinama u smislu približavanja, a ne nešto što možemo izmenom Ustava implementirati u naš sistem. Nakon uvodnih govora predstavnika vlasti koje sam na početku navela, skupu su se obratila dva savetnika iz Američke ambasade koji su izneli neka svoja zapažanja u vezi sa precedentnim pravnim sistemom. Zahvalila sam se kolegama na učešću i podsetila da je i u američkom pravnom sistemu počela kodifikacija pojedinih oblasti prava i da je i kod njih započeta promena sistema koja ih približava kontintalnom pravnom sistemu. Ukazala sam da advokatura prati promene u sferi prava i u anglo-saksonskom pravu i da sam sa zadovoljstvom čitala dela američkog teoretičara prava - Dvorkina. Takođe sam istakla da se slobodno sudijsko uverenje u američkom sistemu neguje, budući da je gdin Čedomir Backović upućivao da toga nema u američkom sistemu kao i da je ono i kod nas precenjeno.

Iznela sam primedbu da rasprava bez teksta predloga izmena Ustava nije plodonosna, da tema sudska praksa kao izvor prava mora najpre dobiti ocenu stručne javnosti i da tek nakon toga može biti izneta pred celokupnu javnost Srbije. Na kraju sam pozvala Ministarstvo pravde da u okviru poglavlja Pravosuđe organizuje okrugli sto na kojem će tema biti advokatura. 